Andrii RAZMIETAIEV

H.S. Skovoroda Kharkiv National Pedagogical University

Department of Political Science, Sociology and Cultural Science

Kharkiv, Ukraine

andrey.razmetaev@gmail.com

ORCID 0000-0003-0476-051X

https://doi.org/10.34739/dsd.2019.01.10

\title{
INTERNATIONAL ADMINISTRATION IN DONBAS: \\ WAYS OF IMPLEMENTATION ON THE BASIS \\ OF EXPERIENCE OF PEACEKEEPING PROCESSES \\ IN THE BALKANS AND IN EAST TIMOR
}

\begin{abstract}
The article discusses the experience of creation of peacekeeping missions in Bosnia and Herzegovina, Eastern Slavonia, Kosovo and East Timor with the use of comparative method. It also raises the role of international and regional actors in post-conflict peacebuilding. The author presents some practical solutions for the implementation of the effective peace process in eastern Ukraine, aimed at the reintegration of temporarily occupied territories.
\end{abstract}

KEYWORDS: peacekeeping mission, international administration, armed conflict, peace agreement

\section{MIECDZYNARODOWA ADMINISTRACJA W DONBASIE: SPOSOBY IMPLEMENTACJI NA PODSTAWIE DOŚWIADCZEŃ PROCESÓW POKOJOWYCH NA BALKANACH I W TIMORZE WSCHODNIM}

\begin{abstract}
ABSTRAKT: W artykule omówiono doświadczenia związane z funkcjonowaniem misji pokojowych w Bośni i Hercegowinie, Wschodniej Slawonii, Kosowie i Timorze Wschodnim, przy wyjorzystaniu analizy porównawczej. Autor odnosi się do roli międzynarodowych i regionalnych podmiotów w budowaniu pokoju po zakończeniu konfliktu. Przedstawia również praktyczne rozwiązania dotyczące wdrożenia skutecznego procesu pokojowego we wschodniej Ukrainie, mającego na celu reintegrację tymczasowo okupowanych terytoriów.
\end{abstract}

SŁOWA KLUCzowe: misja pokojowa, administracja międzynarodowa, konflikt zbrojny, porozumienie pokojowe

The necessity of implementation of peacekeeping mission in Donbas becomes more and more evident for Ukraine. Political and diplomatic settlement of the armed conflict in the east of the country also meets commitments on peaceful solution of the conflict, undertaken by our country in the EU-Ukraine Association Agreement (article 9). 
Ukraine's aspiration to peaceful way of deoccupation and reintegration of territories in the east of Ukraine was set forth in numerous documents:

- in the so-called "Minsk agreements": Minsk Protocol of 05.09.2014, Minsk Memorandum of 19.09.2014 and Package of Measures for the Implementation of the Minsk Agreements of 12.02.2015;

- Decree of the Verkhovna Rada of Ukraine No. 253-VIII of 17.03.2015 "On Approval of Appeals in the Name of Ukraine to the Security Council of the United Nation Organization and the Council of European Union concerning unfolding international operation on support of peace and safety in Ukraine";

- Law of Ukraine No. 2167-VIII of 06.10.2017 “On Creation of Necessary Conditions for Regulating the Situation in Certain Areas of Donetsk and Luhansk Regions" (hereinafter CADLR).

Moreover, for the implementation of Minsk Agreements the Parliament adopted the Law "On Special Order of Local Self-Government in Certain Areas of Donetsk and Luhansk Regions" as far back as 16.09.2014.

Why in spite of the steps taken by our country the process of peaceful reintegration of CADRL could not be launched within five years? Which steps are to be taken and, what is most important, what kind of actors are to be involved to launch peacekeeping mission in Donbas?

To answer the above questions let us take a brief look at the experience of launching peacekeeping missions in other armed conflicts, their common features and differences in relation to each other and at the situation in Ukraine using comparative approach. When choosing appropriate cases we shall take the following criteria into account: subject, the organization under the auspices of which the mission is implemented, mission mandate, mission success in post-conflict regulation.

The appeals for the implementation of peacekeeping mission not just with security potential, but first of all with wide administrative powers, i.e. international interim (or transitional) administration can be heard with increasing frequency in Ukraine ${ }^{1}$. The necessity of creation of transitional administration in Donbas was also expressed by the special representative of the US Department of State Kurt Volker in his interview for the radio station "Echo of Moscow"2. The original offers concerning the mechanisms of international transitional administration in CADRL, aimed at the intensification of Minsk process, were received from the Organization for Security and Co-Operation in Europe ${ }^{3}$.

The examples of immediate international civil-military administration of territories are UN missions in Bosnia and Herzegovina, Eastern Slavonia, Kosovo and East Timor. All these missions were implemented in 1990s as the reaction of the world community to the

\footnotetext{
1 Vide: В МінТОТ назвали головні умови забезпечення миру на Донбасі, http://www.youtube.com/ watch? $=2$ BbTPgaLoiQ (11.03.2019).

${ }^{2}$ Vide: Интервью Курта Волкера, http://echo.msk.ru/programs/beseda/2283826-echo/ (11.03.2019).

${ }^{3}$ В ОБСЕ розповіли про новий план щзоо Донбасу на заміну Мінським угодам, http://www.pravda.co m.ua/news/2019/01/28/7205089/ (11.03.2019).
} 
protracting ethnopolitical conflicts with numerous victims, which had no other solution except for temporary delegation of sovereign power to UN authorities. According to Gregory Fox, the missions were designed to move beyond mere conflict resolution and address the root causes of political dysfunction in states. They seek to create institutions designed to redirect group hostilities into democratic processes. The effort to replace war with politics gave rise to the term "peace-building"4.

First of all, it should be noted that all the four missions were approved by respective resolutions of the UN Security Council. Presently Ukraine is credited with one UN Security Council Resolution No. 2202 of 17.02.2015, which approves the Package of Measures for the Implementation of the Minsk Agreements of 12.02.2015. This resolution, unlike resolutions related to the countries of former Yugoslavia and East Timor, does not provide for creation of peacekeeping mission under the auspices of the UN and the more so the implementation of the regime of international administration in the occupied areas of Donbas. To cut it short the political part of resolution and Minsk Agreements is reduced to giving special status to CADRL and holding extraordinary local elections ${ }^{5}$. According to the opinion of experts of International Centre for Policy Studies, institutionalization of Ukrainian crisis as an internal conflict between Ukraine and CADRL as a result of signing Minsk Agreements makes it impossible to unfold peace-enforcement mission at this stage as Russia is de facto an aggressor country and was de jure removed from the conflict by the UNSC Resolution 2202 and the regulation of the conflict through fulfillment of Minsk Agreements is an obligation of Ukraine, recorded by the UN Security Council ${ }^{6}$.

Secondly, as it has been demonstrated by the experience of creating UN peacekeeping missions, parties to a conflict are to reach an agreement on certain stepwise mechanisms of peaceful regulation, including rebuilding political institutions and establishing democratic regime in post-conflict territories. The Dayton Agreements dated 1995 and Rambouillet Agreements dated 1999 even included new constitutions for Bosnia and Herzegovina and Kosovo respectively. These agreements involved not only UN transitional administration, but also interested regional subjects as actors to the political process. Thus, UN mission in Kosovo (UNMIK) included four components: the UN was responsible for law and order and civil administration, Organization for Security and Co-Operation in Europe (OSCE) was responsible for democratization and institution building, European Union (EU) was responsible for economic reconstruction ${ }^{7}$.

The only exception was the so-called "Erdut Agreement" of 15.11.1995, signed by the Prime-Minister of Croatia of that time, Hrvoje Šarinić, and the representative of separatist

\footnotetext{
${ }^{4}$ G. Fox. Humanitarian Occupation, Cambridge 2008, p. 9.

${ }^{5}$ UN Security Council Resolution 2202 (Feb. 17, 2015), http://undocs.org/en/S/RES/2202(2015) (11.03.2019).

6 В. Філіпчук, Міжнародна миротворчість та війна на Сході Украйни: чи є точки дотику?: превентивна дипломатія, миротворчість, підтримка миру та миробудівництво у врегулюванні «Українського конфлікту», Київ 2016, с. 20.

7 United Nations Interim Administration Mission in Kosovo (UNMIK), http://peacekeeping.un.org/en/miss ion/unmik (11.03.2019).
} 
Serb Krajina, which provided for peaceful end of the war in Croatia and transitional period for reintegration of its territories by Serbian own forces. This small document was of approximately the same volume as Package of Measures for the Implementation of the Minsk Agreements (14 items vs 13). The Erdut Agreement provided for unfolding of the United Nations Transitional Administration for Eastern Slavonia, Baranja and Western Sirmium (UNTAES), which was exercise control over the region in the transitional period, including the organization of holding elections to all local authorities ${ }^{8}$. It should be noted that neither the agreement, nor the UNSC Resolution 1033 (1995), by which UNTAES was established, provided for any special status for these territories for pro-Serbian powers. The Erdut Agreement delegated wide discretionary powers for international administration also in security area by providing for demilitarization of the region "according to the schedule and procedures determined by the international force" ". In contrast, Minsk Agreements do not provide for which subject(s) are going to exercise authoritative powers in transitional period, in particular, who is responsible for the organization and holding of local elections in CADRL, how the illegitimate authorities of occupation administration of the Russian Federation in Donetsk and Luhansk Regions are to be dissolved, how the issues of returning of internally displaced persons and of the residential property and other property, which was lost due to occupation, etc. are to be solved. Gaps in normative regulation of these issues and constant appeals on the part of Russia that Ukraine has to reach direct agreements with the socalled "DPR" and "LPR", obviously block the launch of peacekeeping process in Donbas.

Therefore, the Erdut Agreement and Minsk Agreements have significant differences, witnessing of far more advantageous position of Croatia as compared to Ukraine. For Ukraine the variant of signing new agreement with pro-Russian powers in Donbas is unacceptable, as it will have negative consequences in form of legitimization of the "DPR" and "LPR" as independent political actors. Moreover, the mission in Croatia from the start was not aimed at giving of special status for post-conflict territories, unlike Rambouillet Agreements for Kosovo or Minsk Agreements for CADRL. E.g., UNTAES Transitional Administrator in 1996-1997, Jacques Paul Klein, declared expressly to the Serbians returning to Eastern Slavonia, that they would not get an autonomous region in Croatia and reintegration is their only variant ${ }^{10}$. If Ukraine happens to agree on practical implementation of "special status" for CADRL and signing additional "peace plans" with separatists at high level, it will be more likely to promote secession rather than reintegration of the occupied territories.

Thirdly, reaching the agreement itself between the participants of the armed conflict is of crucial importance for the success of peacekeeping process.

\footnotetext{
${ }^{8}$ Basic agreement for Eastern Slavonia, Baranja and Western Sirmium, http://undocs.org/en/\%20S/1995/951 (11.03.2019).

${ }^{9}$ Ibidem.

${ }^{10}$ J.-P. Klein, The United Nations Transitional Administration in Eastern Slavonia (UNTAES). Proceedings of the Annual Meeting (American Society of International Law), Vol. 97 (April 2-5, 2003), p. 207
} 
In this respect the experience of Dayton Peace Agreements of December 14, 1995 as an example of the elimination of undesired actors from the negotiation process is useful for Ukraine. Bosnian Serbs were the only obstacle on the way to reaching the agreement on postconflict peacebuilding. On the eve of Dayton negotiations they controlled about seventy per cent of the territory of Bosnia, gained as a result of a series of campaigns of ethnic cleansings and thus had more losses from peace plan on creation of multiethnical national government. This made their consent of critical importance for any kind of settlement. But the leadership of Bosnian Serbs was not present in Dayton. Radovan Karadžić and Ratko Mladić were accused by the International Criminal Tribunal for the former Yugoslavia (ICTY) on the eve of negotiations for their role in mass murder of Muslims in Srebrenica. Because of abrupt position of the prosecutors and judges of the ICTY and the US Special Envoy to the Balkans Richard Holbrooke, who declared the necessity of arresting Karadžić and Mladić, Slobodan Milošević, the Serbian President at that time, signed the agreements in Dayton allegedly on behalf of Bosnian Serbs ${ }^{11}$. In this respect Milošević took the role of the representative of the whole "Serbian world". This legal fiction was completely in the interests of other participants of Dayton negotiations. Such a stroke of diplomacy is also possible for reaching an agreement with Russia concerning the representation by Russian official persons of "DPR" and "LPR" at the negotiations without the participation of quasi-state subjects, which are qualified in Ukraine as terrorist organizations ${ }^{12}$. An additional argument of immediate involvement of the Russian party can be the recognition by the Parliamentary Assembly of the Council of Europe CADRL as "territories temporarily under the effective control of the Russian authorities" in $2018^{13}$.

As in case with Ukraine, the parties to the conflicts often did not seek reconciliation especially on disadvantageous terms. E.g., during the conference in Rambouillet in February 1999 aimed at peaceful settlement for Kosovo, Belgrade refused to sign draft agreements, as under numerous provisions of these documents Serbia de facto lost its sovereignty over Kosovo. Only after NATO bomb attacks in March 1999 aimed at gaining consent of Belgrade to the project, proposed in Rambouillet, the Serbian party reached the agreement on a peace plan with EU envoy Martti Ahtisaari and a special envoy of the Russian Federation Victor Chernomyrdin. Under the NATO military pressure Rambouillet project had triumphed ${ }^{14}$.

Fourthly, the internationalization of the conflict and involvement of independent outside actors into post-conflict regulation are of great importance.

\footnotetext{
${ }^{11}$ Ф. Хартманн, Мир и наказание: Тайные войны международной политики и правосудия, Харьков 2018, c. $160-161$.

12 Vide Заява Верховної Ради України «Про визнання Україною юрисдикиії Міжнародного кримінального суду щзодо скоєння злочинів проти людяності та воєнних злочинів вищими посадовими особами Російської Федерації та керівниками терористичних організацій «ДНР» та «ЛНР», які призвели до особливо тяжких наслідків та масового вбивства украӥнських громадян» № 145-VIII від 04.02.2015 р., http://zakon3.rada.gov.ua/laws/show/145-19 (11.03.2019).

13 State of emergency: proportionality issues concerning derogations under Article 15 of the European Convention on Human Rights: Resolution 2209 (2018), http://assembly.coe.int/nw/xml/XRef/Xref-XML2HT ML-en.asp?fileid=24680\&lang=ru (11.03.2019).

${ }^{14}$ G. Fox, op.cit, p. 92.
} 
In this respect the experience of deoccupation of East Timor is an example of political settlement, which can take Ukraine out of harmful discourse of "internal conflict" which is actively propagated by the Russian Federation in the information warfare against Ukraine. Indonesia occupied East Timor in 1975 after Portuguese colonial power left the isle. Though not a single country (except of Australia) acknowledged the sovereignty of Indonesia over the East Timor and the UN authorities described it as a case of incomplete decolonization ${ }^{15}$, there was not enough collective pressure to provide for withdrawal of the Indonesians. Moreover, unlike constant East Timor resistance to occupation the interest of international community to the situation occurring got weakened in a couple of years. In 1980s the tone of the UN resolutions got down significantly, they didn't mention the right of people of East Timor to self-determination and the seizure of Indonesian occupation anymore ${ }^{16}$. Only Portugal was consistent in its advocating interests of East Timor and tried to come to common decision with Indonesia concerning the status of the occupied territory. Persistent efforts of this country ended in signing the agreement between the governments of Portugal and Indonesia on May 5, 1999, in which the determination of the political status of the island was put to the referendum ${ }^{17}$.

It is worth saying that this peace agreement, just like in case of Balkan agreements, continued the discourse of preserving territorial integrity of the countries, which were the objects of postconflict peacebuilding. The document was only about granting East Timor the status of special autonomy within the unitary Republic of Indonesia ${ }^{18}$. The UNSC Resolution 1246 (1999) adopted for the implementation of this agreement provided for holding a popular consultation "in order to ascertain whether the East Timorese people accept the proposed constitutional framework providing for a special autonomy for East Timor within the unitary Republic of Indonesia or reject the proposed special autonomy for East Timor"19. As in the case of Kosovo, the presumption of the autonomous status as an instrument for postconflict settlement was a time bomb waiting to explode, which opened the way for gaining sovereignty of the injured ethnos.

In June 1999 the Security Council sent the United Nations mission in East Timor (UNAMET) for the organization and monitoring the voting. Seventy per cent of the inhabitants voted for the independence which resulted in an unrest and violence over indigenous population on the part of pro-Indonesian forces. Under the UN pressure and the perspective of economic sanctions, primarily from USA, which threatened to veto loans and aid amounting to billiards of dollars, Indonesia was forced to a wider United Nations mandate and implementation of peacekeeping mission ${ }^{20}$. On October 25, 1999 the Security Council

\footnotetext{
${ }^{15}$ GA Res. 389 (Apr. 22, 1976), http://undocs.org/en/S/RES/389 (11.03.2019).

${ }^{16}$ Question of East Timor, GA Res. $37 / 3$ (Nov. 23, 1982), http://undocs.org/en/A/RES/37/30 (11.03.2019).

${ }_{17}^{17}$ Report of the Secretary-General, Question of East Timor, http://undocs.org/en/S/1999/513 (11.03.2019).

${ }^{18}$ Ibidem.

${ }^{19}$ UN Security Council Resolution 1246 (Jun. 11, 1999), http://undocs.org/en/S/RES/1246 (11.03.2019).

${ }^{20}$ Р. Джеффрі, Злочини проти людства: Боротьба за правосуддя в усьому світі, Одеса 2006, с. 455-456.
} 
adopted the Resolution 1272, which provided for creation of United Nations Transitional Administration in Eastern Timor (UNTAET) ${ }^{21}$. UNTAET ruled the territory for three years and ended on May 20, 2002 when East Timor became an independent UN member-state.

The United Nations peacekeeping mission in East Timor shows that not only immediate participants of the armed conflict, but also other countries, which are ready to undertake the obligations of political participation in the settlement of a conflict can be parties to postconflict peacebuilding. In addition, if for reaching the agreements between the parties to conflict in Bosnia, Kosovo and Croatia on ending armed confrontation and postconflict regulation military coercion mostly from NATO to peace was of great importance, gaining agreement from Indonesia for presence of peacekeepers in East Timor became possible mostly due to economic pressure. It should be noted that the efficiency of this kind of influence was also conditioned by the fact that Indonesia was in hard economic condition due to Asian financial crisis of 1997, which resulted in political instability and fall of Suharto dictatorship in 1998. If comparing to Ukraine we can come to the conclusion that the chances for reaching the agreement with Russia on peaceful deoccupation of Donbas rise in case of economic weakening and political instability of the Kremlin.

Taking into account the experience of peacekeeping missions in Balkans, the external actors, interested in peaceful regulation of the conflict in Donbas are to be European Union and the EU member states as conflict in Donbas is the biggest threat for the system of European security since the wars in Yugoslavia. Further the development of the negotiation process in "Normandy format" is perspective.

\section{CONCLUSIONS}

The history of creation of the United Nations Transitional Administration in Balkans and East Timor in 1990s shows that international and regional security actors, UN, NATO, OSCE, EU, demanded from participants of the armed conflicts the achievement of agreements concerning future peacebuilding. The measures of forcing diplomacy, e.g. military actions (Serbia and Croatia), economic sanctions (Indonesia), criminal prosecution (Bosnia) were of not least importance in the emergence of international administrators, who separated opposing parties. In case of Donbas the pressure over Russia in order to gain its agreement to peaceful reintegration of CADRL is to be secured mainly by the economic sanctions.

The conditions of creation of international administration in East Timor, significant inequality of the parties, prolonged occupation, non-military enforcement actions on a party to a conflict are the closest to Ukrainian realities. In its turn the most applicable for reintegration of Ukrainian territories is the experience of United Nations Transitional Administration in East Slavonia. Two other missions, in Bosnia and Kosovo, were relatively successful, as they stopped the armed conflicts, but had negative political consequences for preserving the

\footnotetext{
${ }^{21}$ UN Security Council Resolution 1272 (Oct. 25, 1999), http://undocs.org/en/S/RES/1272(1999) (11.03.2019).
} 
sovereignty of postconflict states. In first case, Bosnia failed to become a full-fledged state and the power in the country belongs to the so-called "three constitutional peoples": Serbs, Bosnians and Croatians ${ }^{22}$. In the other case granting autonomous status to Kosovo under the international administration resulted in alienation of sovereignty of Serbia over this territory and proclaiming independence by Kosovo parliament in $2008^{23}$. The last mission is also an example of the dangers of peacekeeping process around autonomous status of one of the parties to a conflict.

In the existing state of affairs the variant with international administration in Donbas under the auspices of the UN seems to be the only possible mechanism for deoccupation and reintegration of these territories. For this Ukraine is to get released from the institutional trap of Minsk Agreements, which were entered into at a disadvantage of the threat of a full-scale war with Russian Federation in 2014-2015 and produce a discourse of "internal conflict" in Donbas. Presently new international documents are required which would directly provide for the creation of United Nations Transitional Administration in Donbas with accessory role of OSCE authorities (holding local elections and creation of democratic institutions) and EU (donation and economic reconstruction). The most acceptable variant will be signing multilateral document in "Normandy format": between Ukraine (power giving its consent to transitional administration of its sovereign territories), the Russian Federation (occupying power, giving its consent to seizure of effective control over CADRL), Germany and France (intermediaries in peacekeeping process).

\section{BIBLIOGRAPHY}

Basic agreement for Eastern Slavonia, Baranja and Western Sirmium, http://undocs.org/en/ $\% 20 \mathrm{~S} / 1995 / 951$.

General Assembly, Resolution 389. 1976. https://undocs.org/en/S/RES/389.

General Assembly, Resolution 37/3. 1982. Question of East Timor, http://undocs.org/en/ $\mathrm{A} / \mathrm{RES} / 37 / 30$.

Fox Gregory. 2008. Humanitarian Occupation. Cambridge: Cambridge University Press.

Klein Jacques-Paul. 2003. „The United Nations Transitional Administration in Eastern Slavonia (UNTAES)". Proceedings of the Annual Meeting (American Society of International Law) (97): 205-209.

Parliamentary Assembly of the Council of Europe, Resolution 2209. 2018. State of emergency: proportionality issues concerning derogations under Article 15 of the European Convention on Human Rights, http://assembly.coe.int/nw/xml/XRef/XrefXML2HTML-en.asp?fileid=24680\&lang=ru.

Report of the Secretary-General, S/1999/513. 1999. Question of East Timor, http://undocs.org/en/S/1999/513.

\footnotetext{
${ }^{22}$ В. Забара, Політичні перетворення «післядейтонської» Боснії і Герцеговини (1996-2012 рр.): проблеми періодизації, 2013, „Історичний архів” (10), с. 38.

23 О. Каравайцева, Незалежність Косово: історія та міжнародні наслідки конфлікту, http://nbuv.gov.ua/UJRN/appol_2013_50_13 (11.03.2019).
} 
United Nations Interim Administration Mission in Kosovo (UNMIK), http://peacekeeping.un.org/en/mission/unmik.

United Nation Security Council, Resolution 1246. 1999. http://undocs.org/en/S/RES/1246.

United Nation Security Council, Resolution 1272. 1999. http://undocs.org/en/ S/RES/1272(1999).

United Nation Security Council, Resolution 2202. 2015. http://undocs.org/en/ S/RES/2202(2015).

В МінТОТ назвали головні умови забезпечення миру на Донбасі [V MinTOT nazvaly holovni umovy zabezpechennia myru na Donbasi], http://www.youtube.com/ watch? $\mathrm{v}=2 \mathrm{BbTPgaLoiQ}$

В ОБСЄ розповіли про новий план щодо Донбасу на заміну Мінським угодам [V OBSIe rozpovily pro novyi plan shchodo Donbasu na zaminu Minskym uhodam], http://www.pravda.com.ua/news/2019/01/28/7205089/.

Интервью Курта Волкера [Intervyu Kurta Volkera], http:/echo.msk.ru/programs/ beseda/2283826-echo/.

Забара Владислав. 2013. „Політичні перетворення 'післядейтонської’ Боснії і Герцеговини (1996-2012рр.): проблеми періодизації”. Історичний архів (10): 38-44. [Zabara Vladyslav. 2013. „Politychni peretvorennia 'pisliadeitonskoi' Bosnii i Hertsehovyny (19962012 rr.): problemy periodyzatsii”. Istorychnyi arkhiv (10): 38-44].

Заява Верховної Ради України «Про визнання Україною юрисдикції Міжнародного кримінального суду щодо скоєння злочинів проти людяності та воєнних злочинів вищими посадовими особами Російської Федерації та керівниками терористичних організацій «ДНР» та «ЛНР», які призвели до особливо тяжких наслідків та масового вбивства українських громадян» від 04.02.2015 p. № 145-VIII [Zaiava Verkhovnoi Rady Ukrainy «Pro vyznannia Ukrainoiu yurysdyktsii Mizhnarodnoho kryminalnoho sudu shchodo skoiennia zlochyniv proty liudianosti ta voiennykh zlochyniv vyshchymy posadovymy osobamy Rosiiskoi Federatsii ta kerivnykamy terorystychnykh orhanizatsii «DNR» ta «LNR», yaki pryzvely do osoblyvo tiazhkykh naslidkiv ta masovoho vbyvstva ukrainskykh hromadian» vid 04.02.2015 r. № 145VIII], http://zakon3.rada.gov.ua/laws/show/145-19.

Каравайцева Олена. 2013. „Незалежність Косово: історія та міжнародні наслідки конфлікту". Актуальні проблеми політики (50): 111-120 [Karavaitseva Olena. 2013. „Nezalezhnist Kosovo: istoriia ta mizhnarodni naslidky konfliktu”. Aktualni problemy polityky (50): 111-120], http://nbuv.gov.ua/UJRN/appol_2013_50_13.

Робертсон Джеффрі. 2006. Злочини проти людства: Боротьба за правосуддя в усьому світі. Одеса: АО БАХВА [Robertson Dzheffri. 2006. Zlochyny proty liudstva: Borotba za pravosuddia v usomu sviti. Odesa: AO BAKhVA].

Філіпчук Василь. 2016. Міжнародна миротворчість та війна на Сході України: чи є точки дотику?: превентивна дипломатія, миротворчість, підтримка миру та миробудівництво у врегулюванні «Українського конфлікту». Київ: Міжнародний Центр Перспективних досліджень [Filipchuk Vasyl. 2016. Mizhnarodna myrotvorchist ta viina na Skhodi Ukrainy: chy ye tochky dotyku? : preventyvna dyplomatiia, myrotvorchist, pidtrymka myru ta myrobudivnytstvo u vrehuliuvanni «Ukrainskoho konfliktu». Kyiv: Mizhnarodnyi Tsentr Perspektyvnykh doslidzhen].

Хартманн Флоренс. 2018. Мир и наказание: Тайные войны международной политики и правосудия. Харьков: Юрайт [Hartmann Florens. 2018. Mir i nakazanie: Taynyie 